\title{
A vibrating feeder tray improves bullfrog production
}

\author{
Eduardo Pahor-Filho*, Marcelo Maia Pereira, Marta Verardino De Stéfani \\ Aquaculture Center of the Universidade Estadual Paulista, CAUNESP, Jaboticabal 14884-900, SP, Brazil
}

\section{A R T I C L E I N F O}

\section{Article history:}

Received 26 April 2015

Received in revised form 1 July 2015

Accepted 1 July 2015

Available online 3 July 2015

\section{Keywords:}

Production parameters

Lithobates catesbeianus

Feed management

Food movement

Survival

\begin{abstract}
A B S T R A C T
Studies have developed techniques for bullfrog feeding in which movement of the food stimulates food intake in the absence of housefly larvae. We analyze a completely randomized design with two treatments (vibrating tray and linear feeder) in triplicate. A total of 1800 bullfrog froglets (Lithobates catesbeianus) $(7.60 \pm 0.59 \mathrm{~g})$ were divided in six pens of $12 \mathrm{~m}^{2}$ and density $25 / \mathrm{m}^{2}$. Three fattening pens contained linear cement feeders $(3.0 \times 0.50 \mathrm{~m})$ with a $\mathrm{V}$-shaped bottom that crossed the pen longitudinally at each side of the pool containing commercial diet ( $40 \%$ crude protein) with added $5 \%$ housefly larvae. In the other three pens, six vibrating feeders trays $(80 \times 34 \mathrm{~cm})$ per pen were arranged linearly, three at each side of the pool with commercial ration without housefly larvae. The productive performance of frogs was assessed by weight gain, feed intake, feed conversion, specific growth rate and survival by 90 days. We observed that bullfrog froglets receiving food in a vibrating feeder tray present better productive performance (weight gain, feed conversion and specific growth rate) than animals fed ration and housefly larvae in a linear feeder. This response can be related to the greater visual stimulus of the food by frogs fed in vibrating feeder trays, in which food had greater movement.
\end{abstract}

(c) 2015 Elsevier B.V. All rights reserved.

\section{Introduction}

In bullfrog rearing, movement of the food is an important feed stimulus. In the wild, these animals feed on small insects and invertebrates that actively move in terrestrial and aquatic environments (Hirai, 2004; Silva et al., 2009). Within this context, recent studies have shown that the movement of inert food can increase the food intake of frogs on commercial frog farms, improving live weight gain and feed conversion (Castro et al., 2012). These achievements open new perspectives for frog farming. In this respect, the improvement of feeding techniques is necessary to reduce the cost of frog production in captivity.

The Anfigranja system, the main frog production system in Brazil, was designed to contain shelters, a pool and feeders for supplying ration, as well as housefly larvae that stimulate food intake by the animals (Lima et al., 2003). Other production systems can be adopted on commercial frog farms depending on the financial conditions of each producer. These systems include the vertical system (Rodríguez-Serna et al., 1996) and flooded system (Oliveira et al., 2009), in which the water moves the feed stimulating the food consumption. The absence of housefly larvae minimizes the stigma

\footnotetext{
* Corresponding author. Tel.: +55 1632092615.

E-mail address: efpahor@gmail.com (E. Pahor-Filho).
}

and may contribute to increase the consumption of frog meat by consumers.

Since bullfrog meat is an important commercial product, the production of these animals in modern and more hygienic systems may render the cost of the end product more feasible for the producer, in addition to increasing meat consumption by consumers. This study analyzed the productive performance of bullfrog froglets fed in vibrating or linear feeder in the Anfigranja system. In this respect, we suggest here the use of vibrating feeder tray for bullfrog feeding in this system. The vibrating feeder tray results in increased movement of feed pellets and may improve feed consumption and growth rate of bullfrog froglets.

\section{Material and methods}

\subsection{Animals}

A total of 1800 Lithobates catesbeianus froglets $(7.60 \pm 0.59 \mathrm{~g})$ were divided into six fattening pens $\left(12 \mathrm{~m}^{2}\right)$ in an experimental facility containing basic equipment (a pool, shelters, and troughs) arranged in a linear manner according to Lima (1997). The frogs were housed at a density of 25 animals $/ \mathrm{m}^{2}$. Water from an artesian well was supplied continuously. During the experimental protocol, the water quality parameters were maintained in the acceptable range for bullfrog growth: temperature $\left(27.8^{\circ} \mathrm{C}\right), \mathrm{pH}$ $(7.26 \pm 0.12)$, dissolved $\mathrm{O}_{2}\left(7.33 \pm 0.76 \mathrm{mg} \mathrm{L}^{-1}\right)$, Total Ammonia 

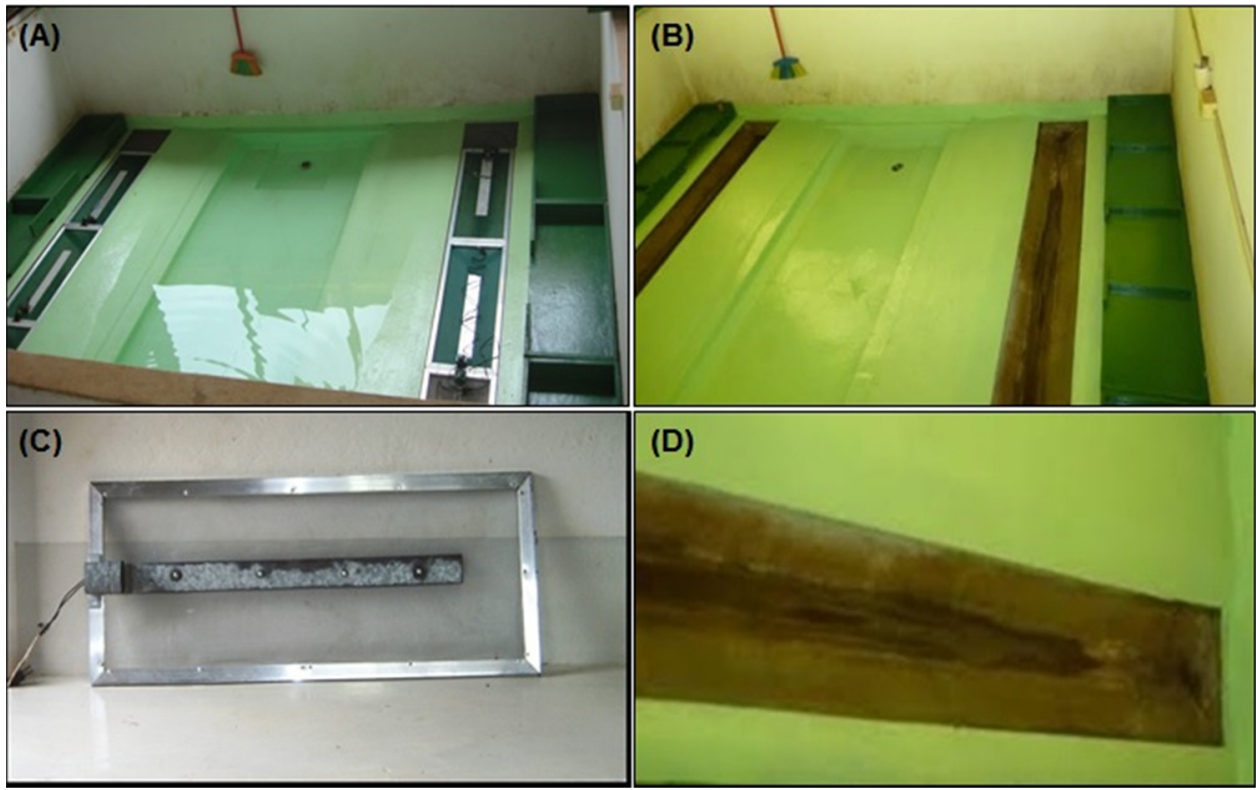

(D)

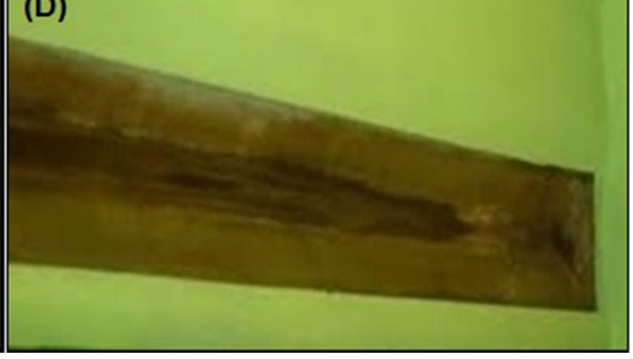

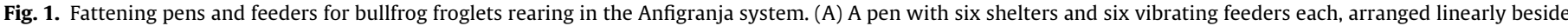

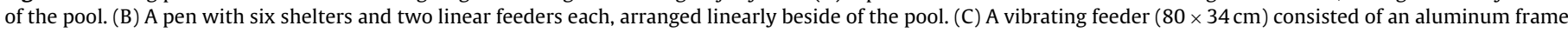

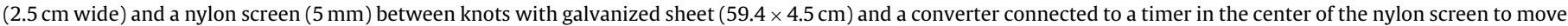
the food. (D) A linear cement feeder $(3.0 \times 0.50 \mathrm{~m})$ with a V-shaped bottom.

Nitrogen $\left(0.21 \pm 0.03 \mathrm{mg} \mathrm{L}^{-1}\right)$ and photoperiod $(12 \mathrm{~h})$. The parameters measurement was performed using an oximeter and a $\mathrm{pH}$ meter YSI 55 and Nessler's reagent for ammonia.

\subsection{Study design}

Basically, the frogs were submitted to different types of feeding (two treatments). In the first treatment, the animals received ration and housefly larvae in a linear feeder. In the second treatment, the animals received the same ration without larvae in a vibrating feeder tray. Next, total population sampling was performed to determine production parameters of the animals (weight gain, food intake, feed conversion, survival, and specific growth rate) at three different time points (30,60 and 90 days) in the summer. The feed was been distributed on the feeder tray manually by a producer twice daily according to $5 \%$ of total body weight measured monthly. The total biomass value was readjusted following each biometric measurement.

\subsection{Specific procedures}

\subsubsection{Pens with linear feeders}

Three fattening pens (Fig. 1B) contained linear cement feeders $(3.0 \times 0.50 \mathrm{~m})$ with a V-shaped bottom that crossed the pen longitudinally at each side of the pool (Fig. 1D). Commercial diet FRI-AQUA ${ }^{\circledR}$ (40\% crude protein, $6-8 \mathrm{~mm}$ pellet) with added $5 \%$ housefly larvae according to Aleixo et al. (1984) determined by the wet weight to stimulate food intake was supplied until apparent satiety of the animals. Cleaning of the pens, exchange of the pool water and removal of leftovers were performed daily.

\subsubsection{Pens with vibrating feeder trays}

In the other three pens, six vibrating feeder trays $(80 \times 34 \mathrm{~cm})$ per pen were arranged linearly, three at each side of the pool (Fig. 1A). Each vibrating feeder tray consisted of an aluminum frame $(2.5 \mathrm{~cm}$ wide $)$ and a nylon screen $(5 \mathrm{~mm})$ between knots. A galvanized sheet $(59.4 \times 4.5 \mathrm{~cm})$ with a converter connected to a timer was placed in the center of the nylon screen. The galvanized sheet moves the food and stimulates food intake by the animals (Fig. 1C). The same commercial ration containing $40 \%$ crude protein was supplied until apparent satiety of the animals, but without the addition of housefly larvae. The vibrating feeders were activated from 7:00 to $19: 00 \mathrm{~h}$. The vibrating feeder trays remained $15 \mathrm{~min}$ on (each feeding period) and 15 min off. The vibrating feeder tray does not throw the food in the water. It simply vibrates and moves slightly all portion food stimulating the frogs feeding on the vibrating feeder tray. If the feed falls into the water, the frogs do not eat.

\subsubsection{Productive performance}

The productive performance of the frogs was evaluated at $0-30,31-60$ and $61-90$ days by the measurement of weight gain, food intake, feed conversion, survival, and specific growth rate ( $S G R=\ln$ (final live weight) $-\ln$ (initial live weight)/experimental days]. A sample of $20 \%$ of the frogs was weighed monthly in each experimental pen. For calculation of the amount of ingested food and feed conversion on a dry matter basis, leftovers (diet and housefly larvae) were removed, stored in a freezer, and subsequently dried in an oven with forced air circulation at $105^{\circ} \mathrm{C}$ for $12 \mathrm{~h}$.

\subsubsection{Statistical analysis}

Data of weight gain, food intake, feed conversion, specific growth rate and survival were analyzed regarding normality and homoscedasticity by the Shapiro-Wilk and Bartlett tests, respectively, and after submitted to analysis of variance. Significant differences between treatments were analyzed by the Duncan test ( $\alpha=0.05$ ) using the SAS Institute (2008) program.

\section{Results}

The weight gain and feed conversion of frogs feeding in the vibrating feeder tray was higher than that of animals feeding in the linear feeder after day 60 of the study period. In ninety days of experiment, weight gain $(240.48 \pm 16.49 \mathrm{~g})$, feed conversion $(1.10 \pm 0.01)$ and the specific growth rate $(4.85 \pm 0.15 \% /$ day $)$ 
Table 1

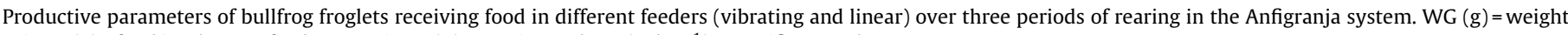
gain, $\mathrm{FI}(\mathrm{g})=$ food intake, $\mathrm{FC}=$ feed conversion, $\mathrm{S}(\%)=$ survive and $\mathrm{SGR}\left(\%\right.$ day $\left.^{-1}\right)=$ specific growth rate.

\begin{tabular}{|c|c|c|c|c|c|c|}
\hline \multirow[t]{2}{*}{ Parameter } & \multirow[t]{2}{*}{ Type of feeder } & \multicolumn{4}{|l|}{ Period } & \multirow[t]{2}{*}{ Mean } \\
\hline & & $0-30$ & $31-60$ & $61-90$ & $0-90$ & \\
\hline \multirow[t]{2}{*}{ WG (g) } & Vibrating & $65.44 \pm 4.41^{\mathrm{bA}}$ & $88.33 \pm 7.43^{a \mathrm{~A}}$ & $86.70 \pm 6.14^{a \mathrm{~A}}$ & $240.48 \pm 16.49^{\mathrm{A}}$ & $80.16 \pm 5.4^{\mathrm{A}}$ \\
\hline & Linear & $63.16 \pm 2.44^{\mathrm{bA}}$ & $85.53 \pm 6.71^{a} \mathrm{~A}$ & $50.21 \pm 3.94^{\mathrm{bB}}$ & $198.91 \pm 15.99^{B}$ & $66.30 \pm 5.33^{B}$ \\
\hline \multirow[t]{2}{*}{$\mathrm{FI}(\mathrm{g})$} & Vibrating & $68.32 \pm 4.94$ & $96.78 \pm 3.75$ & $100.11 \pm 5.99$ & $265.22 \pm 14.80$ & $88.40 \pm 7.39$ \\
\hline & Linear & $71.16 \pm 3.22$ & $92.91 \pm 4.23$ & $85.10 \pm 2.63$ & $249.17 \pm 7.22$ & $83.05 \pm 3.61$ \\
\hline \multirow[t]{2}{*}{ FC } & Vibrating & $1.03 \pm 0.08^{\mathrm{aA}}$ & $1.10 \pm 0.05^{\mathrm{aA}}$ & $1.14 \pm 0.03^{\mathrm{aA}}$ & $1.10 \pm 0.01^{\mathrm{A}}$ & $1.09 \pm 0.03^{\mathrm{A}}$ \\
\hline & Linear & $1.13 \pm 0.08^{\mathrm{aA}}$ & $1.08 \pm 0.05^{\mathrm{aA}}$ & $1.72 \pm 0.06^{\mathrm{bB}}$ & $1.31 \pm 0.12^{\mathrm{B}}$ & $1.31 \pm 0.11^{\mathrm{B}}$ \\
\hline \multirow[t]{2}{*}{$\mathrm{S}(\%)$} & Vibrating & $82.83 \pm 16.1$ & $90.00 \pm 0.50$ & $99.93 \pm 0.33$ & $93.72 \pm 5.41$ & $93.72 \pm 5.40$ \\
\hline & Linear & $99.50 \pm 0.28$ & $99.50 \pm 0.28$ & $94.66 \pm 3.52$ & $97.89 \pm 1.30$ & $97.88 \pm 1.30$ \\
\hline \multirow[t]{2}{*}{ SGR $\left(\%\right.$ day $\left.^{-1}\right)$} & Vibrating & $4.27 \pm 0.02$ & $4.95 \pm 0.03$ & $5.31 \pm 0.05$ & $4.85 \pm 0.15^{\mathrm{A}}$ & $4.84 \pm 0.15^{\mathrm{A}}$ \\
\hline & Linear & $4.12 \pm 0.03$ & $4.88 \pm 0.01$ & $5.18 \pm 0.05$ & $4.73 \pm 0.16^{\mathrm{B}}$ & $4.73 \pm 0.15^{\mathrm{B}}$ \\
\hline \multirow[t]{2}{*}{$P$-value } & & & & & & \\
\hline & Type of feeder & & \multicolumn{2}{|c|}{ Type of feeder $\times$ period } & $\mathrm{CV}(\%)$ & \\
\hline WG & 0.0161 & & 0.0234 & & 14.35 & \\
\hline FI & 0.4295 & & 0.5476 & & 16.19 & \\
\hline FC & 0.0128 & & 0.0159 & & 3.13 & \\
\hline Survival & 0.4650 & & 0.2949 & & 10.83 & \\
\hline SGR & 0.0037 & & 0.6142 & & 8.85 & \\
\hline
\end{tabular}

${ }^{1}$ For type of feeder, the same uppercase letters in the same column do not differ by ANOVA (5\% level of significance).

${ }^{2}$ For experimental period, the same lowercase letters in the same line do not differ by Duncan's test (5\% level of significance).

were significantly higher for animals feeding in vibrating feeder trays compared to those receiving ration and housefly larvae in a linear feeder. No significant differences in food intake or survival were observed between treatments (Table 1).

\section{Discussion}

In the present study, we observed that bullfrogs receiving food in a vibrating feeder tray showed better productive performance than animals fed ration and housefly larvae in a linear feeder. This response can be related to the greater visual stimulus of the food by frogs fed in vibrating feeder tray, in which food had greater movement (Fig. 2).

In the wild, frogs are carnivorous and prefer to eat insects and small fish, among other animals (Jancowski and Orchard, 2013). Recent studies have suggested feeding strategies that move the food in order to increase food intake and, thus, to transfer the feeding behavior of these animals in the wild to captivity (Oliveira et al., 2009; Castro et al., 2012). Because of their carnivorous habit frogs are very skilled animals to perceive the feed movement in the production systems (Neveu, 2011). In this respect, automatic dispensers that release food into the water in flooded systems have been shown to effectively contribute to increase the food intake of bullfrogs (Oliveira et al., 2009). According to these authors, this finding is related to the constant movement of the food in water. Positive effects such as better productive performance and feed conversion have been observed in bullfrogs fed at high frequency (up to 46 meals per day), also related to high movement of inert food (Castro et al., 2012). Corroborating theses authors, we observed that the greater movement of food improved the production performance. Although food consumption was statistically similar in both treatments, it is possible that there was more visual stimulation of food by frogs fed in the vibrating feeder tray, where the food movement was noticeably bigger. This greater visual stimulation may have caused better feed efficiency, improving weight gain and feed conversion of these animals compared to frogs fed in linear feeders in which the movement of food, even constant was lower.

In this study, the weight gain $(240.48 \pm 16.49 \mathrm{~g})$, feed conversion $(1.10 \pm 0.01)$ and the specific growth rate $(4.85 \pm 0.15 \% /$ day $)$ were significantly higher for animals feeding in vibrating feeder tray compared to those receiving ration and housefly larvae in a linear feeder. However, there was a significant improvement of weight gain $(86.70 \pm 6.14)$ and feed conversion $(1.14 \pm 0.03)$ of frogs from sixty days of the experiment. This fact can be related to the time the animals need for to learn ingest inert food in the captivity systems. According to Suboski (1992) although frogs have huge ability to perform cognitive movement and its food consumption to be stimulated by food movement, the youngest animals need a time of learning to adapt fully to ingest feed pellets in captivity systems, which in adulthood already occurs normally.

Formerly, housefly larvae was used in frog production systems to make the food move. These insects are part of the natural food of frogs, corresponding to $0.85 \%$ of dietary protein and to $83 \%$ of digestibility of crude protein (Olvera-Novoa et al., 2007). The prejudice and rejection by consumers are the main factors limiting the use of larvae on frog farms (Lima et al., 1999), and it is therefore necessary to reduce the use of these insects for frog feeding (Real et al., 2005). In the present study, we suggested a feeding strategy that does not use housefly larvae. In addition to the cost of the production of these insects, we showed that, during the production cycle studied here, frogs fed ration and fly larvae in linear feeders exhibited poorer productive performance than animals receiving only ration in vibrating feeder tray. It is likely that the visual stimulation of food by frogs fed the linear feeders was small. The movement of food in linear feeders was noticeably lower than in vibrating feeder tray, causing worst weight gain $(198.91 \pm 15.99 \mathrm{~g})$, feed conversion $(1.31 \pm 0,12)$ and specific growth rate $(4.73 \pm 0.16 \% /$ day $)$ at the end of the experimental period.

This study compared the productive performance of bullfrog froglets reared in the Anfigranja system and receiving food in different feeders. We suggest the use of a production system with vibrating feeder tray since the animals showed better weight gain, feed conversion and specific growth rate. There is no need to use fly larvae on the frog farm, thus avoiding an increase in production costs. This is an important step to minimize the stigma of frog meat production. Further studies are needed to compare the costs of different production systems in order to provide data for producers so that they can choose the best system for their property. 

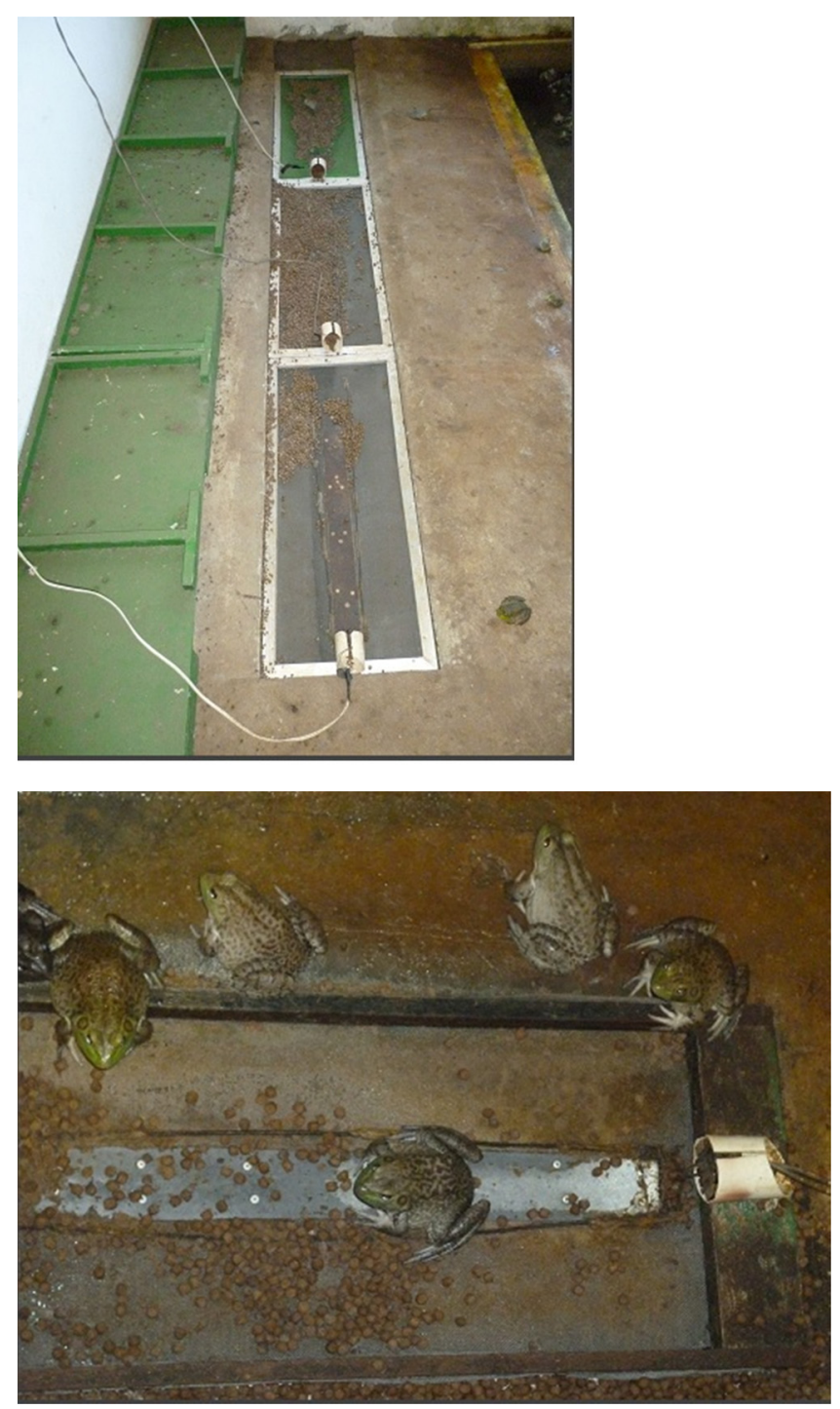

Fig. 2. Anfigranja system with vibrating feeders. Note the frogs are eating on the feeder. The vibrating feeder does not throw the food in the water. It simply vibrates and moves slightly all portion food stimulating the frogs feeding. If the feed falls into the water, the frogs do not eat.

\section{References}

Aleixo, P.G.T., Lima, S.L., Agostinho, C.A., 1984. Criação de moscas domésticas para suplementação alimentar de rãs. UFV, Viçosa, MG, pp. 12 (Informe Técnico, 46). Castro, C.S., Agostinho, C.A., Argentim, D., Alexandre, J.S., Oliveira, L.C., Sousa, R.M.R., Padilha, P.M., 2012. Feed digestibility and productive performance of bullfrogs fed in high and low frequency. Aquaculture 326, 123-128.

Hirai, T., 2004. Diet composition of introduced bullfrog, Rana catesbeiana, in the Mizorogaike Pond of Kyoto, Japan. Ecol. Res. 19, 375-380.

Jancowski, K., Orchard, S.A., 2013. Stomach contents from invasive American bullfrogs Rana catesbeiana (Lithobates catesbeianus) on southern Vancouver Island, British Columbia, Canada. NeoBiota 16, 17-37.

Lima, S.L., 1997. Criação de rãs (Sistema Anfigranja). CPT, Viçosa, pp. 48 (Manual Técnico, 8).

Lima, S.L., Cruz, T.A., Moura, O.M., 1999. Ranicultura: análise de cadeia produtiva. Editora Folha de Viçosa, Viçosa, pp. 172

Lima, S.L., Casali, A.P., Agostinho, C.A., 2003. Desempenho zootécnico e percentual de consumo de alimento de rã-touro (Rana catesbeiana) na fase de recria (pós-metamorfose) no sistema anfigranja. Rev. Bras. Zootecn. 32, 505-511.

Neveu, A., 2011. Influence of genotype of froglets belonging to the Rana esculenta hybridogenetic complex in relation to learning capacity to eat pellets. Aquaculture 310, 343-349.

Oliveira, F.A., Agostinho, C.A., Sousa, R.M.R., Lima, S.L., Gonçalves, H.C., Argentim, D., Castro, C.S., 2009. Manejo alimentar com dispensador automático na recria de rã-touro. Arch. Zootecn. 8, 589-592.

Olvera-Novoa, M.A., Ontiveros-Escutia, V.M., Flores-Nava, A., 2007. Optimum protein level for growth in juvenile bullfrog (Rana catesbeiana Shaw, 1802) Aquaculture 266, 191-199.

Real, M., Martínez, I.P., Álvarez, R., 2005. Progressive reductions in the movement induced in food when rearing Rana perezi Seoane, 1885, in captivity. Aquaculture 249, 189-193.

Rodríguez-Serna, M., Flores-Nava, A., Olvera-Novoa, M.A., 1996. Growth and production of bullfrogs Rana catesbeiana Shaw, 1802, at three stocking densities in a vertical intensive culture system. Aquacult. Eng. 15, 233-242.

SAS Institute, 2008. SAS/STAT 9.2 User's Guide. SAS Institute Inc., Cary, NC.

Silva, E.T., Reis, E.P., Feio, R.N., Ribeiro Filho, O.P., 2009. Diet of the invasive frog Lithobates catesbeianus (Shaw, 1802) (Anura: Ranidae) in Viçosa, Minas Gerais State, Brazil. South Am. J. Herpetol. 4, 286-294.

Suboski, M.D., 1992. Releaser-induced recognition learning by amphibians and reptiles. Anim. Learn. Behav. 20, 63-82. 